\title{
CHEMICAL DISSOLVING OF SLUDGE FROM A HIGH LEVEL WASTE TANK AT THE SAVANNAH RIVER PLANT
}

R. F. BRADLEY

A. J. HILL, Jr.

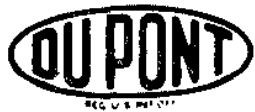

E. I. DU PONT DE NEMOURS AND COMPANY SAVANNAH RIVER LABORATORY AIKEN, SOUTH CAROLINA 29801 


\section{NOTICE}

This report was prepared as an account of work sponsored by the United States Government. Neither the United States nor the United States Department of Energy, nor any of their contractors, subcontractors, or their employees, makes any warranty, express or implied or assumes any legal liability or responsibility for the accuracy, completeness or usefulness of any information, apparatus, product or process disclosed, or represents that its use would not infringe privately owned rights.

Printed in the United States of America

$$
\text { Available from }
$$

National Technical information Service

U.S. Department of Commerce

5285 Port Royal Road

Springtield, Virginia 22161

Price: Printed Copy $\$ 4.00$; Microfiche $\$ 3.00$ 
DP-1471

Distribution Category: UC-70

\section{CHEMICAL DISSOLVING OF SLUDGE FROM A HIGH LEVEL WASTE TANK AT THE SAVANNAH RIVER PLANT}

by

R. F. Bradley and A. J. Hill, Jr.

Approved by

A. S. Jennings, Research Manager Separations Engineering Division

Publication Date: November 1977

E. 1. du PONT de NEMOURS and COMPANY SAVANNAH RIVER LABORATORY AIKEN, SOUTH CAROLINA 29801 


\section{ABSTRACT}

The concept for decontamination and retirement of radioactive liquid waste tanks at the Savannah River Plant (SRP) involves hydraulic slurrying to remove most of the settled sludges followed by chemical dissolving of residual sludges. Dissolving tests were carried out with small samples of sludge from SRP Tank $16 \mathrm{H}$. Over $95 \%$ of the sludge was dissolved by $8 \mathrm{wt} \%$ oxalic acid at $85^{\circ} \mathrm{C}$ with agitation in a two-step dissolving process (50 hours per step) and an initial reagent-to-sludge volume of 20 . Oxalic acid does not attack the waste tank material of construction, appears to be compatible with the existing waste farm processes and equipment after neutralization, and with future processes planned for fixation of the waste into a high-integrity solid for packaging and shipping. 


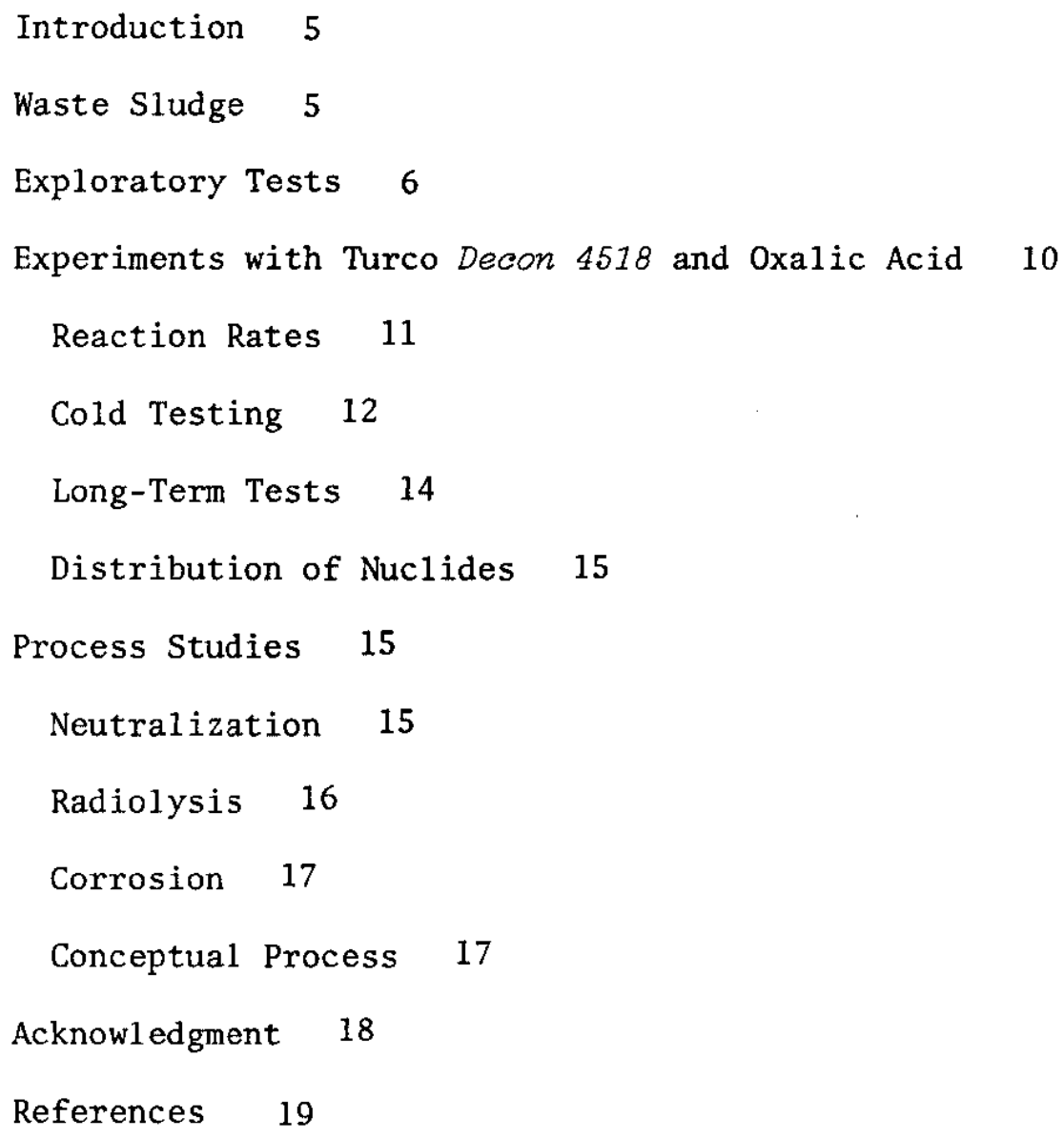




\section{LIST OF FIGURES}

1 Evaluation of Reagents for Dissolving Tank 16 Sludge 9

2 Laboratory Dissolution of Tank 16 Sludge 10

3 Typical Sludge Dissolution Data Conform to FirstOrder Reaction Rate Equation 12

\section{LIST OF TABLES}

1 Major Radionuclides in Tank 16 Sludge 7

2 Calculated Principal Constituents of Washed and Dried Tank 16 Sludge 8

3 Measured Sludge Dissolution Rates 13

4 Dissolution of Simulated Sludge 14 
CHEMICAL DISSOLVING OF SLUDGE FROM A HIGH LEVEL WASTE TANK AT THE SAVANNAH RIVER PLANT

\section{INTRODUCTION}

During the storage of aqueous radioactive wastes at the Savannah River Plant (SRP), a layer of sludge settles to the bottom of the tanks. Twenty-three waste tanks will be retired at SRP in the next decade, and, beginning in 1987, the plan is for waste to be removed from essentially all of the tanks and solidified for storage and shipment. Present waste farm operation, future plans, and strategy for tank decontamination are discussed in References 1,2 , and 3 . Most of the sludge will be removed hydraulically; ${ }^{2}$ however, residual sludges adhering to tank surfaces and interior structures might not be reached by the hydraulic jets. ${ }^{3}$ This residual sludge would be dissolved as described in this report. The sludge samples used for the laboratory tests described in this report were obtained from SRP waste Tank $16 \mathrm{H}$.

\section{WASTE SLUDGE}

The sludge that precipitates and settles to the bottom of a tank during aging of high level waste normally amounts to about 100,000 ga1lons and occupies about one-tenth of the tank volume. About three-fourths of the sludge is compacted into a dark brown, sticky mass; and one-fourth is loosely settled, finely divided material of essentially the same composition. The compacted sludge is generally quite mobile but tends to adhere strongly to objects such as inserted samplers. The adhering sludge usually clings tenaciously to an object when the object is raised through the supernate, but it can be removed readily by flowing water.

The sludge is a mixture of solids and interstitial supernate. The solids in the sludge are generally manganese, iron, and aluminum; the solids also contain uranium, plutonium, and mixed fission products. The exact composition and radioactive content of sludge in any tank depends on the process history of materials in the waste and on the age of the sludge. ${ }^{4}$

If the sludge in Tank 16 is centrifuged and dried without washing, about $80 \%$ is a water-soluble mixture of sodium salts. ${ }^{5}$ The residual sludge is a complex mixture of iron, aluminum, manganese, uranium, and more than 30 other elements principally in the form of hydrous oxides. 
The major radionuclides in sludge that has been centrifuged, washed, and dried are listed in Table 1. The calculated composition of washed and dried sludge is shown in Table 2.

\section{EXPLORATORY TESTS}

Sludge from high activity waste, including that from Tank 16, can be dissolved by boiling in concentrated mineral acids (HC1, $\mathrm{HNO}_{3}-\mathrm{HF}, \mathrm{H}_{2} \mathrm{SO}_{4}$ ). However, prospective reagents for dissolving sludge have been limited to those reagents that will not attack the carbon steel waste tanks or stainless steel processing equipment and will not adversely affect the processes for interim and long-term waste management.

Chemical dissolutions have been conducted with sludge that was thoroughly washed with water and centrifuged but not dried. The amounts of sludge dissolved have been estimated from the volume change of wet centrifuged sludge before and after treatment.

Exploratory tests were conducted with 1 to $2 \mathrm{ml}$ of sludge. The sludge was slurried with $10 \mathrm{ml}$ of the test solution at ambient temperature, $\sim 25^{\circ} \mathrm{C}$. After 30 minutes, the mixture was centrifuged, and the supernatant solution was decanted. The sludge was slurried with water, the water was decanted, and the volume of residual sludge was measured. The procedure was then repeated with the residual sludge, using either fresh solution of the same reagent or a different reagent.

The results of these tests are shown in Figure 1 . Turco Decon 4518 , a mildly acidic solution based on oxalic acid, dissolved $\sim 70$ vol $\%$ of the sludge; this reagent was the most effective of nine reagents tested in the exploratory tests. The distribution of nuclides between solutions and undissolved sludge could not be determined because the quantity of sludge was not sufficient.

* A product of Turco Products, a Division of Purex Corporation, Ltd., Carson, California. 
TABLE 1

Major Radionuclides in Tank 16 Sludge

\begin{tabular}{|c|c|c|}
\hline Nuclide & $\begin{array}{l}\text { Residual Activity } \\
\text { in Centrifuged, } \\
\text { Washed, Dried, Sludge, } \\
\text { dis/(min-g) }\end{array}$ & $\begin{array}{l}\text { Removed by } \\
\text { Two Washes, } \\
\%\end{array}$ \\
\hline${ }^{60} \mathrm{Co}$ & $1.1 \times 10^{11}$ & nil \\
\hline${ }^{90} \mathrm{Sr}$ & $1.9 \times 10^{10}$ & nil \\
\hline $90 \mathrm{ya}$ & $1.9 \times 10^{10}$ & nil \\
\hline${ }^{95} \mathrm{Nb}$ & $1.2 \times 10^{9}$ & nil \\
\hline${ }^{106} \mathrm{Ru}^{b}$ & $3.0 \times 10^{10}$ & nil \\
\hline${ }^{106} \mathrm{Rh}$ & $3.0 \times 10^{10}$ & nil \\
\hline${ }^{134} \mathrm{Cs}$ & $8.9 \times 10^{8}$ & 94 \\
\hline${ }^{137} \mathrm{Cs}$ & $1.6 \times 10^{10}$ & 90 \\
\hline${ }^{137} \mathrm{Ba}^{C}$ & $1.6 \times 10^{10}$ & 90 \\
\hline${ }^{144} \mathrm{Ce}$ & $1 \times 10^{11}$ & nil \\
\hline${ }^{144} \mathrm{Pr}$ & $1 \times 10^{11}$ & ni1 \\
\hline${ }^{147} \mathrm{Pm} d$ & not determined & \\
\hline${ }^{154} \mathrm{Eu}$ & $3.8 \times 10^{10}$ & nil \\
\hline $\mathrm{Pu}^{e}$ & $9.2 \times 10^{8}$ & nil \\
\hline
\end{tabular}

a. Calculated from parent ${ }^{90} \mathrm{Sr}$

b. Calculated from daughter ${ }^{105} \mathrm{Rh}$.

c. Calculated from parent ${ }^{137} \mathrm{Cs}$.

d. ${ }^{147} \mathrm{Pm}$ not determined; estimated $>4 \times 10^{10}$.

e. Total plutonium alpha. 


\section{TABLE 2}

Calculated Principal Constituents of Washed and Dried Tank 16 Sludge ${ }^{\alpha}$

$\begin{array}{ll}\text { Constituent } & w t \% \\ \mathrm{AlO}_{2}^{-} & 16 \\ \mathrm{Fe}^{3+} & 40 \\ \mathrm{MnO}_{2} & 16 \\ \mathrm{Na}^{+} & 20 \\ \mathrm{SO}_{4}^{2-} & 1.1 \\ \mathrm{Si}^{4+} & 2.0 \\ \mathrm{Ba}^{2+} & 1.0 \\ \mathrm{Ca}^{2+} & 1.0 \\ \mathrm{Ce}^{4+} & 1.0 \\ \mathrm{Hg}^{2+} & 2.5 \\ \mathrm{UO}_{2}^{2+} & 0.4\end{array}$

a. Calculated from data for washed and unwashed dried sludge. Estimated relative precision within \pm 30 to $40 \%$. 


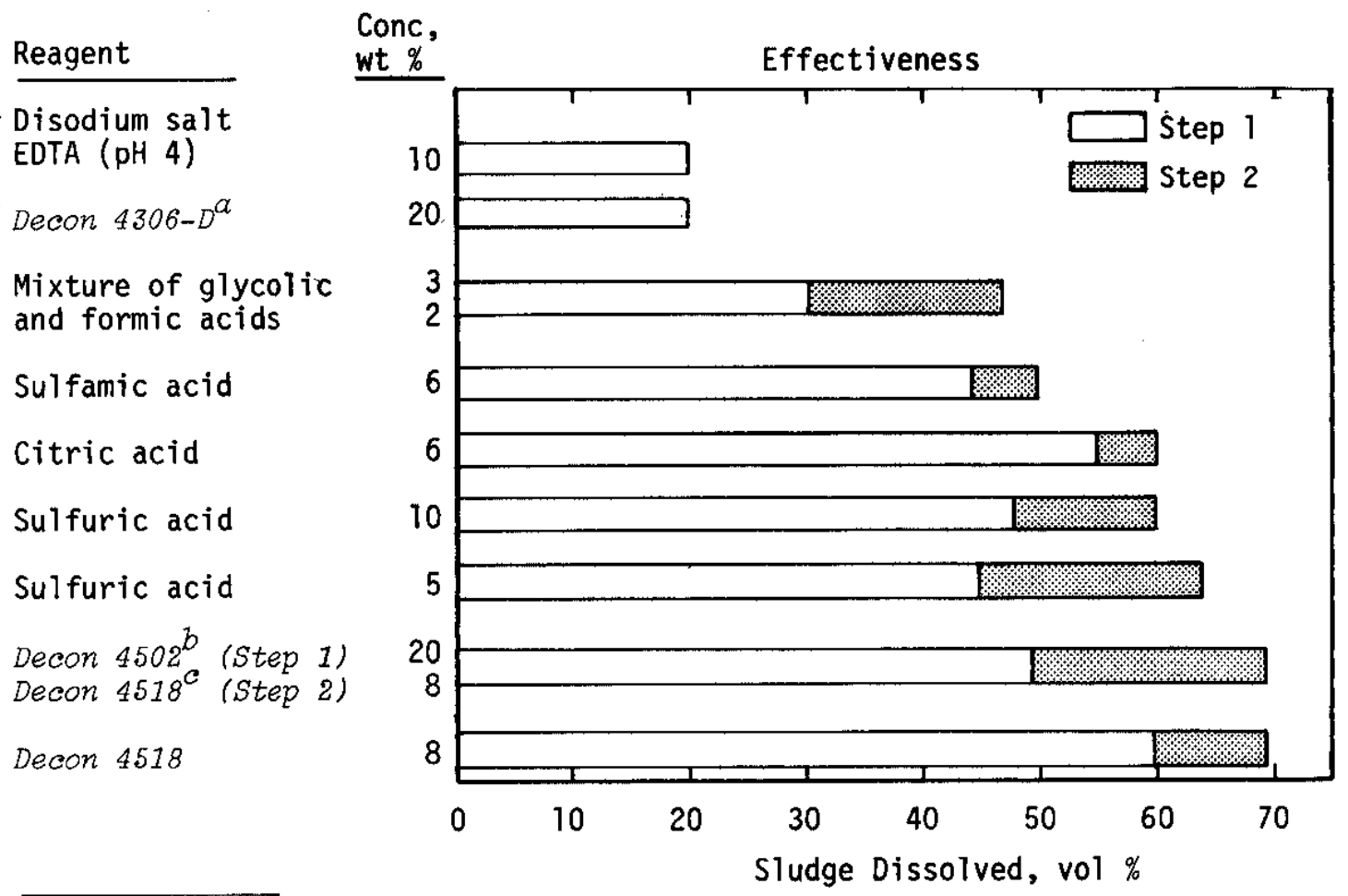

a. Modified sulfamic acid-citric acid composition.

b. Modified arkaline permanganate.

c. Modified oxalic acid composition.

FIGURE 1. Evaluation of Reagents for Dissolving Tank 16 Sludge 
With an $8 \%$ solution of Decon 4518 , omitting the water rinse between two treatments decreased the amount of sludge dissolved to about $53 \%$. Doubling or halving the volume $(10 \mathrm{ml})$ of solution per treatment did not significantly change the amount of sludge dissolved. Reducing the concentration of reagent to $5 \mathrm{wt} \%$ in these experiments had no adverse effect, and increasing it to $16 \%$ had no benefit (Figure 2). Reducing the concentration to $3 \%$ decreased the amount of sludge dissolved to $\sim 35$ vol $\%$.

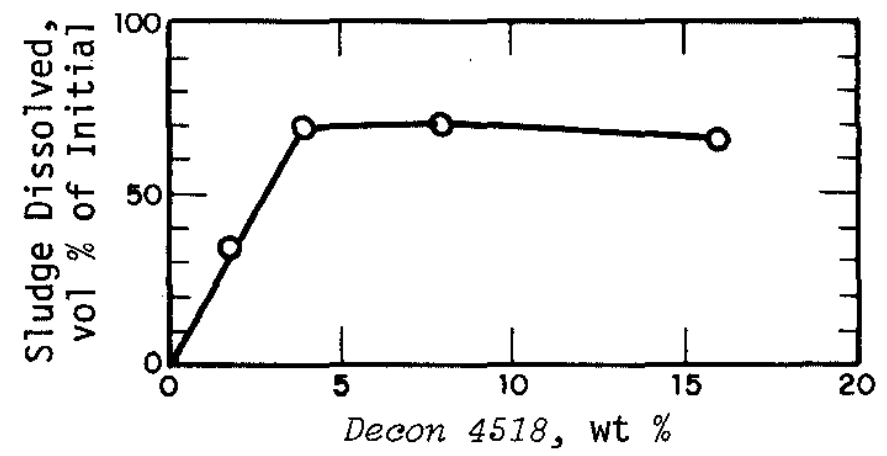

FIGURE 2. Laboratory Dissolution of Tank 16 Sludge

\section{EXPERIMENTS WITH TURCO DECON 4518 AND OXALIC ACID}

Based on the results of the exploratory tests, extensive experiments were conducted with fresh sludge from Tank 16. These tests compared the dissolving capabilities of Decon 4518 with those of oxalic acid (the major component of Decon 4518) and determined the conditions needed to accelerate sludge dissolving and to increase the total amount of sludge that can be dissolved with these reagents. These tests have indicated that, under the same conditions, oxalic acid and Decon 4518 are about equally effective for dissolving sludge. The rate of dissolving increases with increasing temperature, agitation, dissolvent concentration, relative amount of dissolvent, frequency of dissolvent addition, and amount of sludge surface exposed.

As in exploratory experiments, the amount of sludge dissolved was estimated from volume changes of wet centrifuged sludge before and after repeated exposures to fresh dissolvent.

Residual sludge at the end of each exposure was centrifuged, its volume was measured, and the dissolvent was decanted. The sludge was then slurried with water and recentrifuged, and the volume was remeasured. Water was then decanted, and fresh dissolvent was added for the next step. 


\section{Reaction Rates}

Dissolution rate data for each experiment were correlated by assuming a first-order reaction with respect to the quantity of sludge present.

$$
\frac{\mathrm{dM}}{\mathrm{dt}}=-\mathrm{kM}, \ln \frac{\mathrm{M}}{\mathrm{M}_{\mathrm{o}}}=-\mathrm{kt}
$$

where

$$
\begin{aligned}
& M=\text { mass of sludge present at time } t \text { assumed proportional } \\
& M_{0}=\text { mass of sludge initially present }\{\text { to measured volumes } \\
& t=\text { time, } h r \\
& \mathrm{k}=\text { rate constant, } \mathrm{hr}^{-1}
\end{aligned}
$$

Rate data for each experiment fit this equation with only minor deviations; Figure 3 shows typical results (Experiments 9 and 10). Rate constants are 1isted in Table 3 ; larger rate constants indicate faster dissolution. These experiments show that:

1. Oxalic acid and Decon 4518 dissolve Tank 16 sludge at equal rates (Figure 3 ).

2. Continuous agitation increases the dissolution rate $\backsim 30 \%$ (Experiments 7 and 8 ).

3. Increasing the temperature from $25^{\circ}$ to $85^{\circ} \mathrm{C}$ increases the dissolution rate $440 \%$ (Experiments 1 and 2 ).

4. Increasing the Decon 4518 concentration from $4 \%$ to $8 \%$ increases the dissolution rate $\sim 70 \%$ (Experiments 3 and 4 ).

5. The dissolution rate increases in direct proportion to the initial ratio of dissolvent volume to sludge volume (Experiments 6 and 7).

6. Increasing the contact frequency* four times (from $8 \mathrm{hr} / \mathrm{step}$ to $2 \mathrm{hr} / \mathrm{step}$ ) increases the dissolution rate $2130 \%$ (Experiments 5 and 7).

Conclusions 2,3 , and 4 indicate that reaction rate is controlled at least partially by diffusion of dissolvent to the sludge-particle surface. Experiments 5 and 6 indicate that dissolvent is consumed by the reaction. Although mechanisms for

* Frequency at which old solvent is replaced by fresh solvent. 


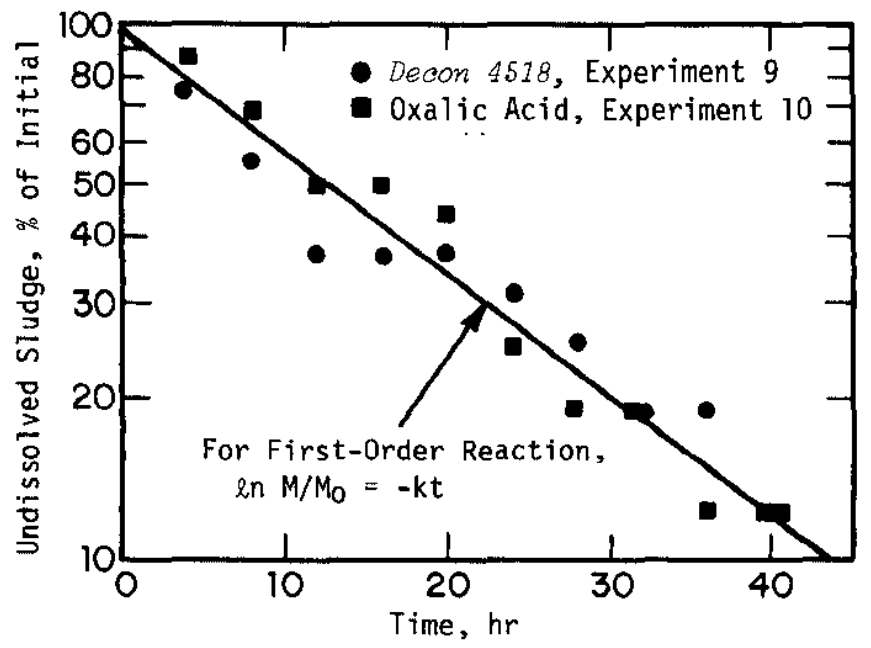

FIGURE 3. Typical Sludge Dissolution Data Conform to First-Order Reaction Rate Equation

sludge dissolution have not yet been determined, one of the principal reactions appears to be that between oxalic acid and ferric hydroxide to form soluble ferric oxalate.

\section{Cold Testing}

With the objective of developing more data on the dissolving of sludge without the necessity of extensive analyses, dissolving tests were conducted in the laboratory with synthesized manganese dioxide and the hydroxides of aluminum and iron. These are the major nonradioactive components of the sludge that are relatively insoluble in water. The hydroxides of aluminum and iron were prepared by reacting aqueous solutions of the nitrate salts with ammonium hydroxide. Manganese dioxide was prepared by the reaction of manganous nitrate in aqueous solution with potassium permanganate.

The procedures used in cold testing were the same as those described for work with Tank 16 sludge. The amount of solid component dissolved was measured by the volume of centrifuged, wet, solid component before and after single or successive treatments.

Aluminum hydroxide dissolved readily in 3 to $6 \mathrm{hr}$ at $80^{\circ} \mathrm{C}$ in $8 \%$ solutions of oxalic acid or Decon 4518 when the volume ratio of reagent-to-solid was at 1 east 20 ; with a ratio of 10 , less than $10 \%$ dissolved. When the concentration of either reagent was reduced to $4 \%$, a flocculent precipitate of aluminum oxalate formed. This precipitate did not compact significantly when centrifuged and resulted in an apparent volume greater than the original volume of aluminum hydroxide. 
TABLE 3

Measured Sludge Dissolution Rates

$\begin{array}{cllllll}\text { Experimental Conditions } \\ \text { No. } & \text { Dissolvent } & \begin{array}{c}\text { Temp, } \\ { }^{\circ} \mathrm{C}\end{array} & \begin{array}{l}\text { Continuous } \\ \text { Agitation? }\end{array} & \begin{array}{l}\text { Initial } \\ \text { Vol. Ratio }\end{array} & \begin{array}{l}\text { Time per } \\ \text { Step, } h r\end{array} & k, h^{-1 b} \\ 1 & 8 \% \text { Decon } 4518 & 25 & \text { No } & 8.7 & 0.5 & 0.9 \\ 2 & 8 \% \text { Decon } 4518 & 85 & \text { No } & 7.0 & 0.5 & 1.2 \\ 3 & 8 \% \text { Decon } 4518 & 85 & \text { No } & 1.8 & 6.0 & 0.1 \\ 4 & 4 \% \text { Decon } 4518 & 85 & \text { No } & 1.8 & 6.0 & 0.06 \\ 5 & 8 \% \text { Decon } 4518 & 85 & \text { No } & 2.0 & 8.0 & 0.07 \\ 6 & 8 \% \text { Decon } 4518 & 85 & \text { No } & 4.8 & 2.0 & 0.4 \\ 7 & 8 \% \text { Decon } 4518 & 85 & \text { No } & 1.4 & 2.0 & 0.15 \\ 8 & 8 \% \text { Decon } 4518 & 85 & \text { Yes } & 1.4 & 2.0 & 0.2 \\ 9 & 8 \% \text { Decon } 4518 & 85 & \text { Yes } & 1.2 & 4.0 & 0.05 \\ 10 & 8 \% \text { Oxalic Acid } & 85 & \text { Yes } & 1.2 & 4.0 & 0.05\end{array}$

a. Dissolvent/Sludge ratio.

b. Dissolution Rate Constant. 
Ferric hydroxide was more difficult to dissolve within the 6 -hr period and required a higher reagent-to-solid ratio for complete dissolving. With a reagent-to-solid ratio of 40 , ferric hydroxide dissolved completely within $6 \mathrm{hr}$ in $8 \%$ oxalic acid, but only $87 \%$ dissolved in Decon 4518.

Manganese dioxide dissolved very slowly even with a high reagent-to-solid ratio indicating that an extended time would be required to dissolve this component of sludge. The results of the more significant experiments in dissolving the nonradioactive components of sludge are summarized in Table 4.

\section{TABLE 4}

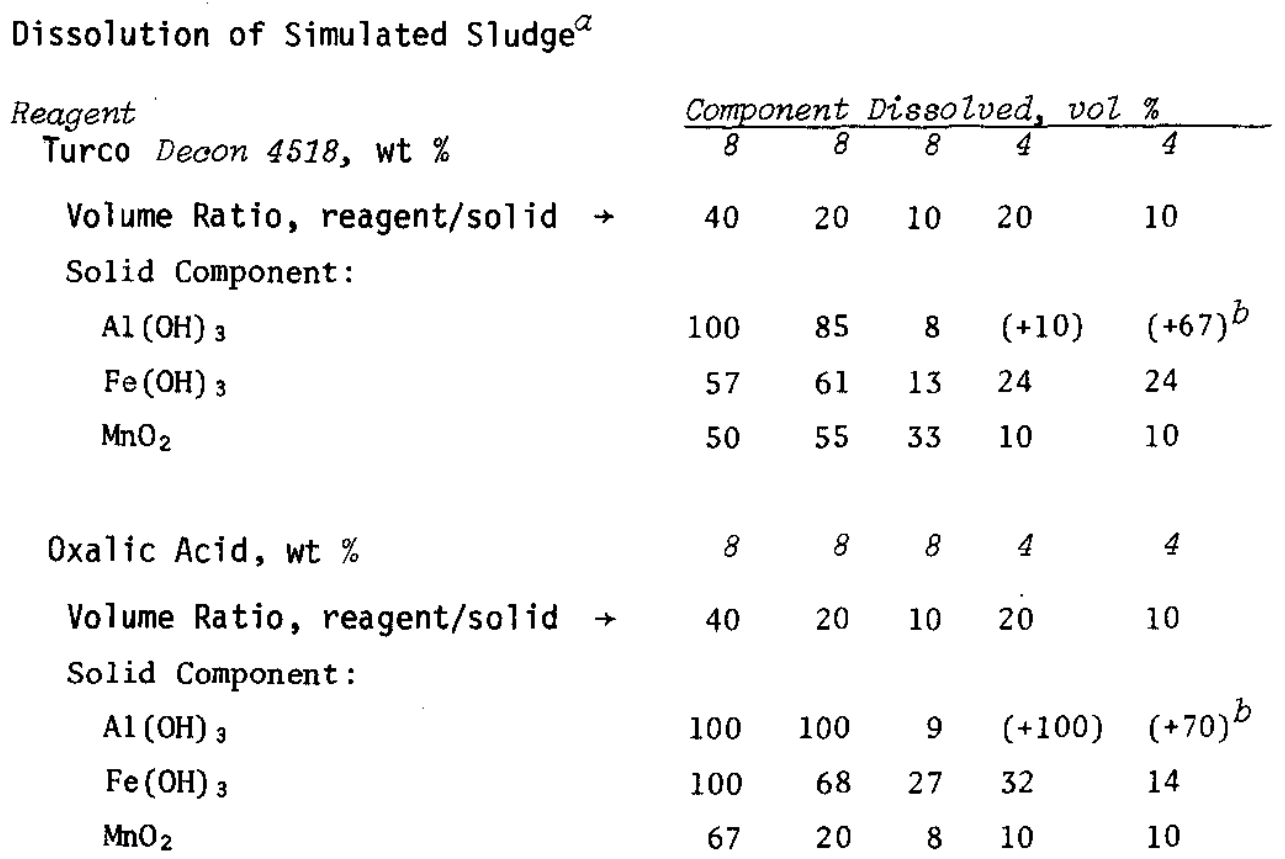

a. Solid dissolved $=$ volume percent; time $=6 \mathrm{hr} ;$ temperature $=55^{\circ} \mathrm{C}$.

$b$. Increase in volume by formation of flocculent precipitate of aluminum oxalate; not concentrated by centrifugation.

\section{Long-Term Tests}

The dissolution rate studies and the results of the experiments with the synthesized nonradioactive components of sludge indicate that further experiments should be conducted with Tank 16 sludge processed for extended periods of time at $85^{\circ} \mathrm{C}$ in $8 \%$ solutions of Decon 4518 and of oxalic acid. Multiple-step experiments were studied with final reagent-to-sludge ratios as high as 80 and 
processing times to 186 hours. These experiments demonstrated that at least $96 \%$ of the sludge can be dissolved in a two-step process of 50 hours per step with an initial reagent-to-sludge ratio of at least 40 . Longer hours of processing or higher reagent-to-sludge ratios did not significantly increase the amount of sludge dissolved with either of these reagents.

\section{Distribution of Nuclides}

The principal isotopes in the sludge presenting a long-term

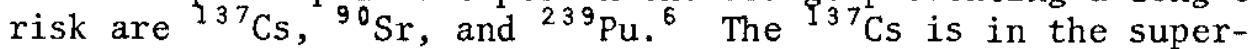
nate phase and is already in solution and easily washed from the sludge. The ${ }^{90} \mathrm{Sr}$ appears to be adsorbed to the hydrous oxides in the sludge and dissolves roughly in proportion to the amount of sludge dissolved in the oxalic acid. Analyses for ${ }^{239} \mathrm{Pu}$ were inconclusive due to small sample sizes; however, there is some indication that a portion of the ${ }^{239} \mathrm{Pu}$ is in a highly insoluble form. Nevertheless, the multiple-step hydraulic slurryingchemical dissolving process should remove more than $99 \%$ of the plutonium in the tank.

\section{PROCESS STUDIES}

\section{Neutralization}

Because the waste tanks are constructed of carbon steel, acidic solutions of high activity waste must be made alkaline before these solutions are stored in the waste tanks. Therefore, experiments were conducted to determine whether the acidic solutions of oxalic acid (or Decon 4518) can feasibly be neutralized before the solutions are pumped to other waste tanks in the system. Solutions of Tank 16 sludge in each of the reagents were made alkaline with $20 \%$ sodium hydroxide to $\mathrm{pH} 11$. The solutions were stirred and allowed to stand. Approximately 10 vol $\%$ of the dissolved sludge precipitated in a few hours from the Decon 4518 solution, and essentially a11 of the sludge precipitated from the oxalic acid solution. With periodic stirring and centrifugation of the sludge to measure the volume, there was no obvious change in the precipitates in four months. Thus, to avoid reprecipitation of part or all of the dissolved sludge in the tank, the solutions can be pumped from the tank and neutralized in a mixing tank enroute to the receiving tank. 


\section{Radiolysis}

There will be some decomposition of the oxalic acid from radiolysis. The principal products of the radiolytic decomposition of oxalic acid are carbon dioxide and hydrogen. In the presence of oxygen, the following reactions are also reported: ${ }^{7}$

$$
\begin{aligned}
& (\mathrm{COOH})_{2}+\mathrm{OH} \cdot \stackrel{\mathrm{O}_{2}, \alpha, \beta, \gamma}{\longrightarrow} \mathrm{CO}_{2}+\mathrm{H}_{2} \mathrm{O}+\mathrm{COOH} \cdot \\
& \mathrm{O}_{2}+\mathrm{H} \cdot \stackrel{\mathrm{O}_{2}, \alpha, \beta, \gamma}{\longrightarrow} \mathrm{HO}_{2} \cdot \\
& \mathrm{COOH} \cdot+\mathrm{HO}_{2} \cdot \stackrel{\mathrm{O}_{2}, \alpha, \beta, \gamma}{\longrightarrow} \mathrm{H}_{2} \mathrm{O}+\mathrm{CO}_{2} \\
& \mathrm{HO}_{2} \cdot+\mathrm{HO}_{2} \cdot \stackrel{\mathrm{O}_{2}, \alpha, \beta, \gamma}{\longrightarrow} \mathrm{H}_{2} \mathrm{O}_{2}+\mathrm{O}_{2}
\end{aligned}
$$

Oxygen is expected to be present because the radiolysis is taking place in solutions containing residual quantities $\left(>10^{-2}\right.$ moles/ liter) of salts. ${ }^{8}$ If the solutions are washed totally free of salts, the oxygen would become depleted after an absorbed dose of $\sim 5 \times 10^{18} \mathrm{eV} / \mathrm{ml}^{7}{ }^{7}$ This dose would be received in Tank 16 within $\sim 2$ to $3 \mathrm{hr}$. Without oxygen, Reactions 2 to 4 are replaced by:

$$
(\mathrm{COOH})_{2}+\mathrm{H} \cdot \stackrel{\alpha, \mathrm{B}, \gamma}{\longrightarrow} \mathrm{H}_{2} \mathrm{O}+\mathrm{CO}_{2}+\mathrm{CHO} \cdot
$$

The $\mathrm{CHO}$ - radicals would undergo further reactions to form other organic species such as polymer products, peroxides, etc.

In addition to Reactions 1 to 5 given in Reference 7 , the reactions of hydrogen atoms and aqueous electrons would be expected to yield molecular hydrogen.

$$
\begin{aligned}
& \mathrm{H} \cdot+\mathrm{H} \cdot \longrightarrow \mathrm{H}_{2} \\
& \mathrm{e}-\mathrm{aq}+{ }_{\mathrm{aq}} \longrightarrow \mathrm{H}_{2}+2 \mathrm{OH}^{-}
\end{aligned}
$$

The hydrogen yield ("G" value) for aqueous oxalic acid solutions is 0.46 molecules $/ 100 \mathrm{eV} .^{9}$ This yield compares with a measured yield of 0.07 molecules $/ 100 \mathrm{eV}$ for synthetic SRP supernate solutions. 8

Based on measured radiation levels in Tank 16 sludge $\left[1.9 \times 10^{10}\right.$

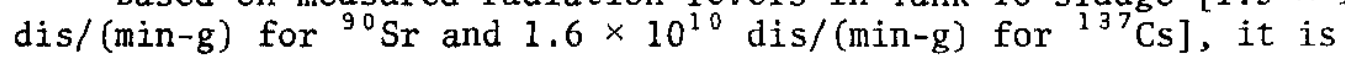
estimated that oxalic acid would be radiolytically destroyed during the chemical cleaning step at a maximum rate of $2 \times 10^{-4}$ moles/ (1iter-hr) for an initial concentration of $\eta_{1}$ mole/liter. Hydrogen would be produced initially in Tank 16 at a rate of $\sim 15$ liters/hr from radiolysis of oxalic acid by residual sludge. 
Oxalic acid will be removed from the tank and neutralized to form sodium oxalate. Although radiolysis of the sodium oxalate should be similar to oxalic acid, laboratory radiolysis studies will be made.

\section{Corrosion}

Corrosion tests indicate there will be no significant corrosion damage to either the carbon steel waste tanks or the stainless steel process equipment by using $8 \%$ solutions of either oxalic acid or Turco Decon 4518 to dissolve high activity waste sludge. Coupons of either ASTM A 285-C carbon steel or AISI 304L stainless steel were exposed in duplicate to solutions of either oxalic acid or Turco Decon 4518 . Solution temperatures were $75^{\circ} \mathrm{C}, 85^{\circ} \mathrm{C}$, and $95^{\circ} \mathrm{C}$; solution concentrations were 4,8 , and $12 \mathrm{wt} \%$.

A11 carbon stee1 coupons became coated with ferrous oxalate dihydrate which was identified by powder $x$-ray diffraction. The highest rates of attack were $0.0006 \mathrm{in./week}$ in $12 \%$ oxalic acid at $95^{\circ} \mathrm{C}$ and 0.0015 in./week in Decon 4518 under the same conditions. Attack rates approximately doubled when the solution was changed daily; little coating occurred under these conditions.

A few of the stainless steel coupons became coated at higher temperatures and concentrations in oxalic acid. In Decon 4518, most of the coupons became coated, and the coated coupons corroded about 100 times faster than the uncoated specimens. However, even at the highest rates, stainless steel did not corrode as fast as carbon steel. The coating was shown to be ferrous oxalate dihydrate, the same as that on the carbon steel samples.

\section{Conceptual Process}

After sludge is removed by slurrying, the residual sludge will be washed twice with water to remove most of the interstitial supernate and the soluble salts in the sludge. Because the purpose of the chemical cleaning process is to remove as much of the remaining radioactivity as possible from the tank, the water and chemical solutions will be introduced through rotating jets under the top of the tank to clean the top, wall, and vertical cooling coils as well as the bottom of the tank. The water in the tank will be recirculated through the large centrifugal slurry pumps to provide good agitation and mixing before the aqueous solution, with any additional suspended solids, is pumped from the tank. Experimental work indicates that at least $60 \%$ of the supernatesludge mixture on the bottom of the tank will be water soluble. 
The major portion ( $>95 \%$ ) of the remaining solids that are not soluble in water will be chemically dissolved in 8 wt \% oxalic acid at $85^{\circ} \mathrm{C}$ in the two-step process described above. The oxalic acid solutions will be prepared in a separate tank and heated to above $85^{\circ} \mathrm{C}$ before they are pumped into the tank through rotary nozzles inside the tank. As in the addition of water, the slurry pumps will provide agitation for mixing the acid with the sludge and for slurrying remaining undissolved solids. The oxalic acid solutions will be transferred to a mixing tank for neutralization. The neutralized solution will be pumped to the evaporator feed tank or hold tank and, after reduction in volume in the evaporator, will be stored in another waste tank.

Following the two-step chemical cleaning, the tank interior will be rinsed twice with water introduced through the spray nozzles and recirculated through the slurry pumps. The rinse water will be pumped from the tank and, after adjustment for $\mathrm{pH}$, will be concentrated by evaporation before it is stored in a waste tank.

The chemical dissolving of sludge will be demonstrated in the SRP waste farm in Tank $16 \mathrm{H}$ beginning in 1978. The goal for activity removal from retired tanks will probably be greater than 99.99\% when the program is implemented. Additiona1 openings in the tanks may be required in order to meet this goal. The primary purpose of the initial Tank $16 \mathrm{H}$ tests is to determine the effectiveness of hydraulic cleaning techniques and the chemical cleaning techniques described in this paper using only existing Tank 16 openings. The sludge removal step, using five pumps in existing risers, is expected to remove about $85 \%$ of the sludge. Efficiencies greater or smaller than that expected should be easily determined in this range. Chemical cleaning is expected to remove about $95 \%$ of that sludge remaining. Again, with the relatively large amount of sludge to be dissolved, measurement of the effectiveness of this step should be relatively straightforward. The combined effectiveness of both steps is thus about 99\%. Water flushing will then be tested for its effectiveness in removing residual activity. Further cleaning beyond water flushing will depend on the extent of decontamination and on criteria for tank cleaning that are not yet formulated.

\section{ACKNOWLEDGMENT}

R. S. Ondrejcin of the Nuclear Materials Division conducted the corrosion tests. 


\section{REFERENCES}

1. Integrated Radioactive Waste Management Plant, Savannah River Plant, Aiken, S.C. USERDA Report SRO-TWM-77-1. Savannah River Operations Office, Aiken, South Carolina (1977).

2. R. F. Bradley, F. A. Parsons, C. B. Goodlett, and R. M. Mobley. A Low Pressure Hydraulic Technique for Slurrying Radioactive Sludges in Waste Tanks. USERDA Report DP-1468, E. I. du Pont de Nemours \& Co., Savannah River Laboratory, Aiken, South Carolina (1977).

3. R. F. Bradley. "Technology for Removing Sludge and Cleaning Savannah River Plant Radioactive Liquid Waste Tanks." Paper presented at the 70th AIChE meeting in New York, New York, November 13-17, 1977.

4. A. J. Hill, Jr. Removal of Sludges from High Activity Waste Tanks. USAEC Report DP-1093, E. I. du Pont de Nemours \& Co., Savannah River Laboratory, Aiken, South Carolina (1967).

5. J. A. Stone. Separation of SRP Waste Sludge and Supemate. USERDA Report DP-1441, E. I. du Pont de Nemours \& Co., Savannah River Laboratory, Aiken, South Carolina (1976).

6. R. F. Bradley and J. C. Corey. Technical Assessment of Bedrock Waste Storage at the Savannah River Plant: USERDA Report DP-1438, E. I. du Pont de Nemours \& Co., Savannah River Laboratory, Aiken, South Carolina (1976).

7. Ivan Draganić. "Oxalic Acid: The Only Aqueous Dosimeter for In-Pile Use." Nucleonics 21 (2), 33 (1963).

8. R. F. Bradley. Radiolysis of Liquid Waste During Bedrock Storage. USAEC Report DP-1264, E. I. du Pont de Nemours \& Co., Savannah River Laboratory, Aiken, South Carolina (1971).

9. J. W. T. Spinks and R. J. Woods. An Introduction to Radiation Chemistry. John Wiley and Sons, Inc., New York (1964). 